\title{
KOMODITAS EKONOMI PADA LINGKUNGAN ENDAPAN BATUBARA
}

\author{
Oleh: \\ SS Rita Susilawati dan Sabtanto Joko Suprapto \\ Bidang Program dan Kerja Sama \\ Pusat Sumber Daya Geologi
}

\begin{abstract}
SARI
Batubara dikenal sebagai salah satu barang tambang yang bernilai ekonomi tinggi. Bersamaan dengan keterdapatan batubara, bisa pula dijumpai komoditi lain yang kemungkinan memiliki nilai ekonomi untuk diusahakan bersama-sama dengan pengusahaan batubara. Sebagai contoh, gas methane yang terperangkap dalam pori-pori lapisan batubara, telah terbukti memiliki nilai ekonomi. Eksplorasi gas methane memberikan keuntungan tidak hanya karena menghasilkan sumber energi yang lebih ramah lingkungan dibandingkan dengan batubara, tetapi juga dapat mengurangi kemungkinan terjadinya ledakan dalam tambang bawah tanah. Selain gas methan, sisa pembakaran batubara berupa abu batu bara, sebaiknya tidak selalu diperlakukan sebagai sampah, karena abu tersebut kemungkinan bisa dimanfaatkan untuk bahan baku dalam industri semien, campuran beton, dan batako.
\end{abstract}

Dalam eksplorasi batubara, perhatian sebaiknya juga diberikan pada komoditas ekonomi lainnya yang kemungkinan ditemukan bersamaan dengan keterdapatan batubara. Sehingga keberadaan seluruh potensi ekonomi bahan tambang yang ada dapat dimanfaatkan secara optimal.

\begin{abstract}
Coal has been known as one of highly economic mining commodity. Along with coal deposit, there might also be occurred other potential commodities associated with coal. For example, methane gas which is trapped in the internal pore of coal bed has been shown to have economic value. Methane gas exploration gives benefit, not only as an energy resources which is considered environmentally more friendly than coal but also could reduce the possibility of explosion in underground coal mine. Other than methane, coal ash, should not only be treated as a waste product, because of its possibility to be used as a raw material in cement, 'batako' and concrete industries.
\end{abstract}

In coal exploration, focus should also be given to the occurrence of other economic commodities which is

\section{PENDAHULUAN}

Di Indonesia, bahan galian batubara, dijumpai dalam jumlah yang sangat besar. Potensi besar batubara terdapat di Pulau Sumatera dan Kalimantan. Batubara terbentuk cenderung berselingan dengan perlapisan sedimen yang lain.

Di dalam suatu sekuen endapan batubara, selain batubara itu sendiri yang bernilai ekonomi, bisa pula dijumpai bahan galian atau mineral ikutan yang bernilai ekonomi. Sebagai contoh, gas metan yang terkandung di dalam batubara, dalam kondisi tertentu kemungkinan juga memiliki potensi untuk dikembangkan menjadi sumber energi ramah lingkungan. Batulempung yang biasanya berselingan dengan lapisan batubara merupakan mineral non logam yang biasa ditambang untuk dijadikan bahan baku untuk beberapa jenis industri. Disamping itu kandungan mineral tertentu di dalam batubara, ketika terbakar dan menjadi abu dapat dimanfaatkan sebagai campuran bahan baku untuk beberapa industri.

Pengembangan potensi batubara mulai dari tahapan eksplorasi sampai eksploitasi sebaiknya memperhitungkan keberadaan komoditas berpotensi ekonomi lainnya yang kemungkinan terkandung di dalam batubara ataupun berada bersamaan dengan keterdapatan batubara. Oleh karena itu, pada saat eksplorasi batubara, sebaiknya juga dilakukan inventarisasi data potensi komoditas lain selain endapan batubara. Data yang diperoleh selain dijadikan dasar dalam 
penanganan batubara pada tahap eksploitasi, sebaiknya juga dipertimbangkan sebagai dasar penanganan atau pengelolaan potensi ikutan lainnya selain batubara.

Pemanfaatan batubara dengan mempertimbangkan seluruh komoditas yang terkandung maupun berasosiasi dengan batubara, diharapkan akan menghasilkan nilai tambah dan hasil yang lebih optimal. Selain itu, bahan yang berpotensi menyebabkan degradasi lingkungan, juga perlu ditangani untuk mengurangi dampak negatif dari penggunaan batubara.

\section{PEMBENTUKAN BATUBARA}

Batubara adalah salah satu bahan bakar yang berasal dari fosil tumbuhan. Pengertian umumnya adalah batuan sedimen yang dapat terbakar, terbentuk dari endapan organik, utamanya adalah sisa-sisa tumbuhan dan terbentuk melalui proses pembatubaraan (coalifikasi). Unsur-unsur utamanya terdiri dari karbon, hidrogen dan oksigen (wikipedia).

Proses pembatubaraan atau proses pembentukan batubara, diawali oleh adanya pertumbuhan tanaman pembentuk batubara di lingkungan rawa-rawa. Tumbuhan tersebut kemudian mati dan terbenam. Tumbuhan baru hidup dan mati. Pada akhirnya sisa-sisa tumbuhan yang mati tersebut membentuk suatu lapisan, yang kemudian menghilang di bawah permukaan air dan terawetkan melalui proses biokimia.

Dalam proses biokimia, adanya aktifitas bakteri mengubah bahan sisa-sisa tumbuhan menjadi gambut (peat). Gambut yang telah terbentuk lambat laun tertimbun oleh endapan-endapan lainnya seperti batulempung, batulanau dan batupasir. Dengan perjalanan waktu yang mungkin berpuluh juta tahun, gambut ini akan mengalami perubahan sifat fisik dan kimia akibat pengaruh tekanan dan temperatur, sehingga berubah menjadi batubara. Pada tahap ini proses pembentukan batubara lebih didominasi oleh proses fisika dan geokimia. Sebagai gambaran untuk batubara dengan tebal $\pm 2 \mathrm{~m}$, dibutuhkan lapisan sisa-sisa tumbuhan dengan ketebalan \pm $60 \mathrm{~m}$.

Selama proses pembentukan batubara, sejumlah besar air dihasilkan bersama-sama dengan gas. Pada proses pembatubaraan, gambut berubah menjadi batubara lignit, batubara bituminous sampai batubara antrasit. Proses perubahan dari gambut menjadi batubara dikenal dengan nama proses pembatubaraan. Peringkat atau tingkat kematangan batubara ini berhubungan langsung dengan temperatur, tekanan, kedalaman timbunan, gradien geotermal dan juga lamanya waktu pembebanan.
Batubara di Indonesia terbentuk dari endapan gambut pada iklim purba sekitar khatulistiwa yang mirip dengan kondisi saat ini.Secara umur, batubara Indonesia yang bernilai ekonomis dapat digolongkan kedalam batubara berumur Miosen serta batubara berumur Eosen. Kedua umur endapan batubara ini terbentuk pada lingkungan lakustrin, dataran pantai atau delta, mirip dengan daerah pembentukan gambut yang terjadi saat ini di daerah timur Sumatera dan sebagian besar Kalimantan.

Beberapa diantara endapan gambut purba yang menjadi cikal bakal batubara Indonesia saat ini, tergolong kubah gambut yang terbentuk di atas muka air tanah rata-rata pada iklim basah sepanjang tahun. Dengan kata lain, kubah gambut ini terbentuk pada kondisi dimana mineral-mineral anorganik yang terbawa air dapat masuk ke dalam sistem dan membentuk lapisan batu bara yang berkadar abu dan sulfur rendah serta menebal secara lokal. Hal ini sangat umum dijumpai pada batu bara Miosen. Sebaliknya, endapan batubara Eosen umumnya lebih tipis, berkadar abu dan sulfur lebih tinggi.

\section{KOMPONEN PADA BATUBARA}

Di dalam dunia industri, kualitas batubara ditentukan oleh komponen-komponen yang ada di dalamnya, yaitu:

\section{Air (moisture)}

Air (moisture) yang terkandung dalam batubara terdiri dari air bebas (free moisture) dan air tertambat (moisture in air dried sample). Air bebas adalah air yang terikat secara mekanik dengan batubara pada permukaan, dalam rekahan atau kapiler dan mempunyai tekanan uap normal.

Air tertambat adalah air yang terikat secara fisik dalam batubara pada struktur pori-pori bagian dalam, dan mempunyai tekanan uap lebih rendah dari pada tekanan normal. Kadar air tertambat dapat dipakai sebagai karakteristik dasar dari batubara, dimana kadar air tertambat bertambah besar dengan menurunnya peringkat batubara.

Batubara dengan kandungan air yang tinggi dianggap kurang begitu bagus kualitasnya karena cenderung menyerap panas selama pembakaran. Batubara jenis ini juga cukup sulit dalam penanganan dan trasportasinya. Kadar air tinggi juga bisa menurunkan nilai kalori dari batubara steam dan juga menurunkan jumlah karbon yang ada dalam batubara kokas.

\section{Abu (ash)}

Yang dimaksud dengan kandungan abu dalam batubara adalah bahan inorganik yang 
tersisa setelah proses pembakaran batubara Kandungan abu tidak sama dengan kandungan mineral matter dalam batubara. Kandungan abu mewakili kandungan mineral matter dalam batubara setelah kehilangan komponen volatilnya seperti $\mathrm{CO}_{2}, \mathrm{SO}_{2}$ dan $\mathrm{H}_{2} \mathrm{O}$, yang menguap pada saat proses pembakaran mineral karbonat, sulfida atau lempung.

Pada batubara steam, kandungan abu yang tinggi akan menurunkan nilai kalori batubara tersebut. Maksimum kandungan abu untuk batubara steam adalah sekitar 20\% (air-dried). Sedangkan, kadar abu yang direkomendasikan untuk penggunaan batubara kokas adalah berkisar antara 10-20\% (air-dried), karena semakin besar kandungan abunya akan semakin menurunkan efisiensi dari tungku pembakaran

\section{Zat terbang (Volatile matter)}

Zat terbang dalam batubara mewakili semua komponen batubara (terkecuali air) yang terbebaskan pada temperatur tinggi pada kondisi tidak ada udara. Komponen zat terbang berasal dari fraksi organik dalam batubara dan juga sedikit dari fraksi anorganik.

Di dalam dunia industri besaran kandungan zat terbang bisa memperngaruhi efektifitas penggunaan batubara. Sebagai contoh, untuk pembangkit tenaga listrik, sebagian besar pembangkit didesain untuk batubara dengan kandungan zat terbang antara 20-25\% (dry ash free). Tetapi dalam industri semen, tidak ada batasan besaran kandungan zat terbang. Dalam industri baja, kandungan zat terbang yang tinggi akan memperendah kualitas baja yang dihasilkan, sehingga batubara kokas yang paling baik untuk digunakan dalam industri baja adalah yang memiliki kandungan zat terbang 20-30\% (air dried) walaupun dalam batubara dengan kisaran zat terbang $16-30 \%$ tetap dapat digunakan.

\section{Karbon tertambat (Fixed Catbon)}

Karbon padat/tertambat adalah karbon yang terdapat pada residu batubara setelah zat terbang terbebaskan. Kandungan karbon padat tidak ditentukan secara langsung tetapi melalui perhitungan. Kadar karbon padat ditentukan oleh kadar air, abu dan zat terbang. Kadar karbon padat adalah : 100\% - \%(air + abu + VM). Semakin tinggi peringkat batubara, semakin tinggi kadar karbonnya.

\section{Unsur-unsur dalam batubara}

Unsur-unsur penting yang terdapat dalam batubara diantaranya adalah karbon, hidrogen, oksigen, belerang dan nitrogen.
Kandungan karbon dan hidrogen menentukan peringkat batubara. Semakin tinggi kandungan karbonnya, semakin tinggi peringkat batubaranya. Karbon dan Hidrogen juga berperan dalam menentukan nilai kalori dari batubara Kandungan nitrogen dalam batubara menjadi penting dalam kaitannya dengan polusi udara. Pada saat pembakaran batubara, nitrogen akan membantu oksida (Nox) yang jika dilepaskan ke atmosfir menyebabkan polusi udara. Oleh sebab itu, batubara yang diminati dalam dunia industri biasanya adalah batubara yang memiliki kadar nitrogen rendah.

Seperti halnya nitrogen, kehadiran unsur sulfur dalam batubara juga bisa menyebabkan masalah dalam pemanfaatan batubara disamping juga bisa menyebabkan polusi udara. Sulfur menyebabkan korosi pada pipa boiler atau mengakibatkan hujan asam.

Oksigen dalam batubara adalah unsur yang terdapat baik pada komponen organik maupun anorganik termasuk juga pada air dalam batubara. Oksigen merupakan indikator penting dalam menentukan rank dari batubara.

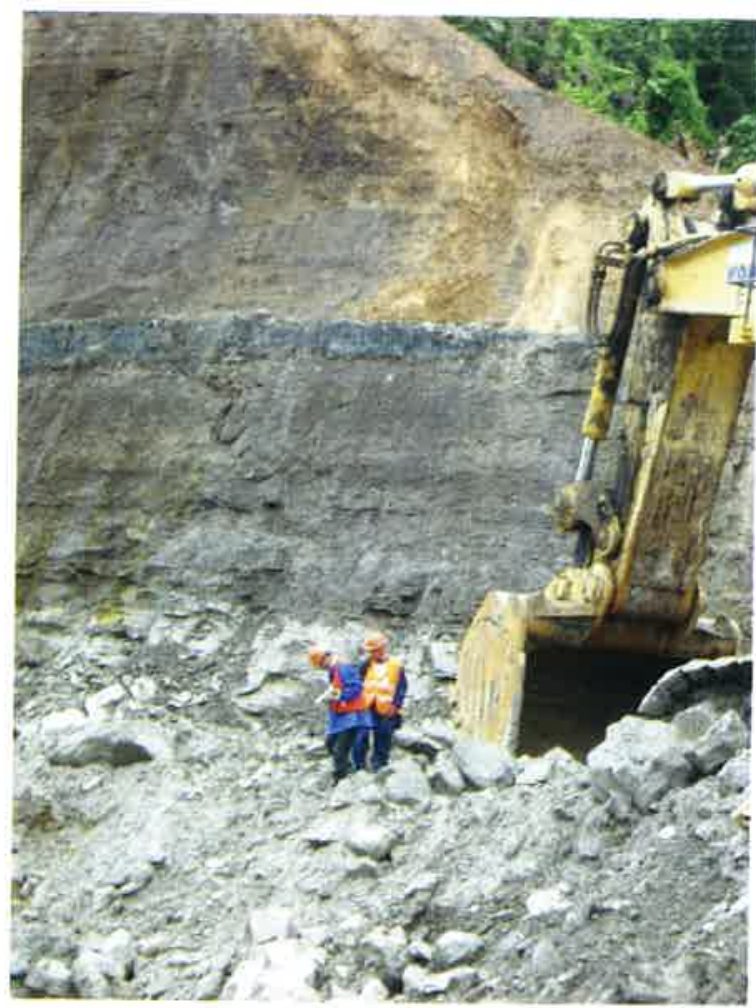

Gambar 1. Penggalian lapisan batulempung pada tambang batubara (Djunaedi dkk 2008)

\section{KOMODITAS EKONOMI YANG BERASOSIASI DENGAN KETERDAPATAN BATUBARA}

Berikut dijelaskan beberapa komoditas ekonomi yang berasosiasi dengan keterdapatan batubara mulai dari yang paling mudah 


\section{MAKALAH ILMIAH}

diusahakan hingga yang membutuhkan investasi tinggi.

\section{Lempung}

Batuan yang umum berasosiasi dengan batubara yaitu batu lempung. Lapisan batu lempung dapat dijumpai sebagai batuan penutup pada tambang batubara atau sisipan di antara seam batubara. Hasil dari analisis major element batu lempung pada beberapa lokasi tambang batubara di Kutai Kartanegara, Kalimantan Timur, menunjukan nilai rata-rata $\mathrm{SiO}_{2} 59.3 \%$ $79.57 \%$, $\mathrm{Al} \mathrm{O}_{3} 15.08 \%-20.96 \%, \mathrm{Fe}_{2} \mathrm{O}_{2} 3.44 \%-$ $17.94 \%, \mathrm{CaO} 0.5 \%-2.12 \%$, MgO 1.1\%-1.92\%, $\mathrm{Na}_{2} \mathrm{O} \quad 0.35 \%-1.53 \%, \mathrm{~K}_{2} \mathrm{O} 1.54 \%-2.51 \%, \mathrm{TiO}_{2}$ $0.7 \%-1.17 \%$, MnO $0.08 \%-0.26 \%, \mathrm{P}_{2} \mathrm{O}_{5} 0.2 \%-$ $0.4 \%$, sO $0.03 \%-0.4 \%, \mathrm{H}_{2} \mathrm{O} 1.4 \%-2.31 \%$. Batu lempung dengan spesifikasi kimia seperti tersebut dapat digunakan antara lain pada industri semen.

Hasil analisis PIMA batulempung mengandung mineral kaolinit, ilit dan halosit. Kualitas lempung tersebut selain dapat digunakan untuk industri semen, berdasarkan hasil uji bakar, mempunyai kualitas baik untuk bahan baku pembuatan tubuh keramik halus (tile dan terra cotta), (Djunaedi dkk, 2008).

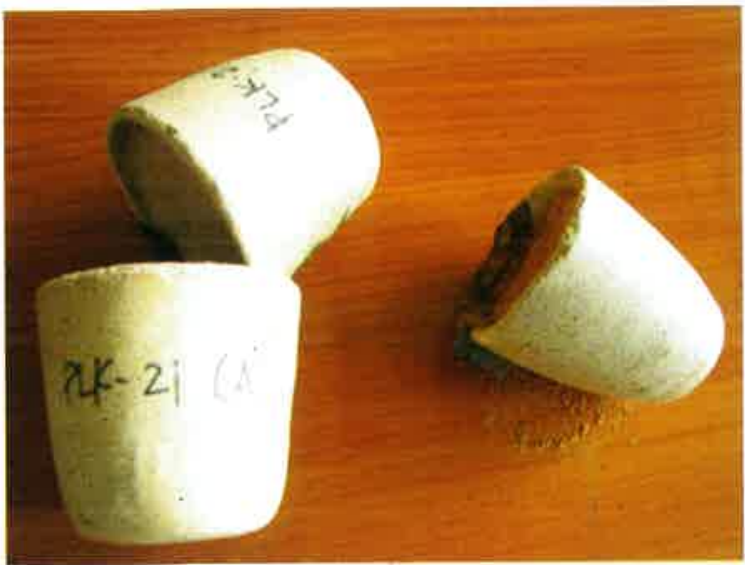

Gambar 2. Keramik hasil uji bakar lempung jenis kaolin (kiri), hasil uji bakar lempung jenis fireclay (kanan)

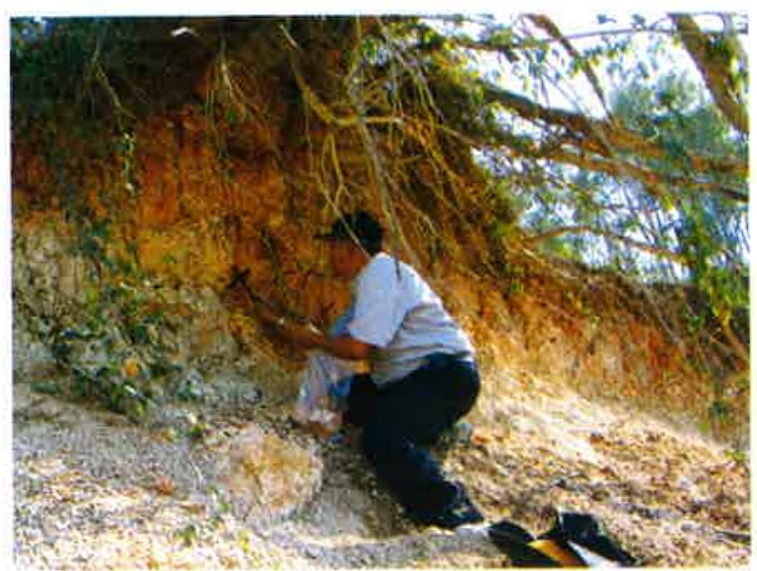

Gambar 3. Fire clay sebagai batuan penutup pada tambang batubara Muaraenim

(Gunradi dkk, 2004)

lempung sebagai tanah penutup pada tambang batubara di Muaraenim, berdasarkan hasil uji bakar dapat digunakan untuk bahan tahan api (fire clay), Gambar 3. Selain itu lempung yang berselingan dengan lapisan batubara di daerah ini, diantaranya merupakan jenis bentonit (Gambar 4). Bentonit mempunyai sifat mengadsorpsi. Kegunaan bentonit tergantung jenis dari bentonit. Na bentonit, dapat digunakan untuk lumpur bor, bahan baku pada industri pengecoran logam, pembuatan pelet konsentrat besi dan logam lain ataupun sebagai bahan pemucat ataupun katalis. Sedangkan, penggunaan utama $\mathrm{Ca}$ bentonit adalah untuk pembuatan $\mathrm{Na}$ bentonit sintetis dan lempung aktif. Ca bentonit juga digunakan dalam industri pelumas, minyak goreng, farmasi, kimia, kertas, dan keramik.

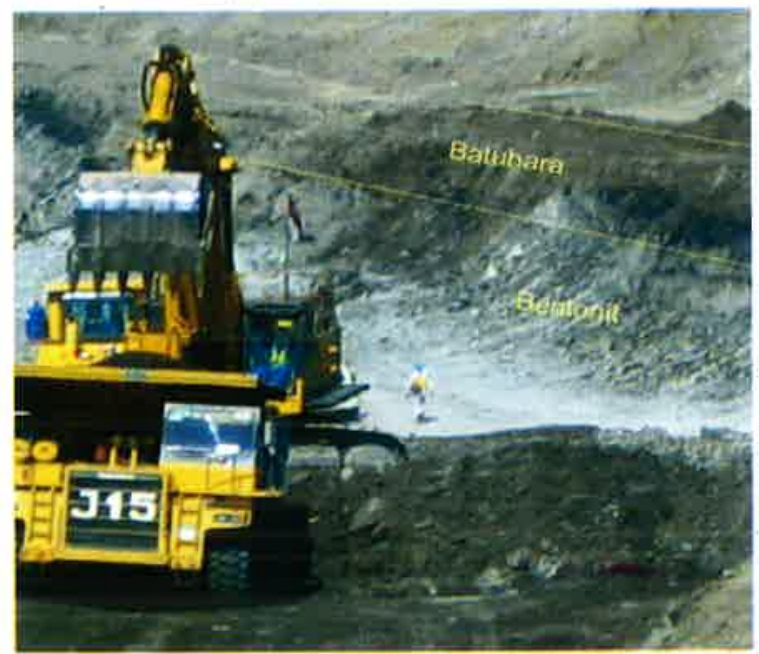

Gambar 4: Lapisan bentonit (warna putih) pada tambang batubara Muaraenim

(Gunradi dkk, 2005) 


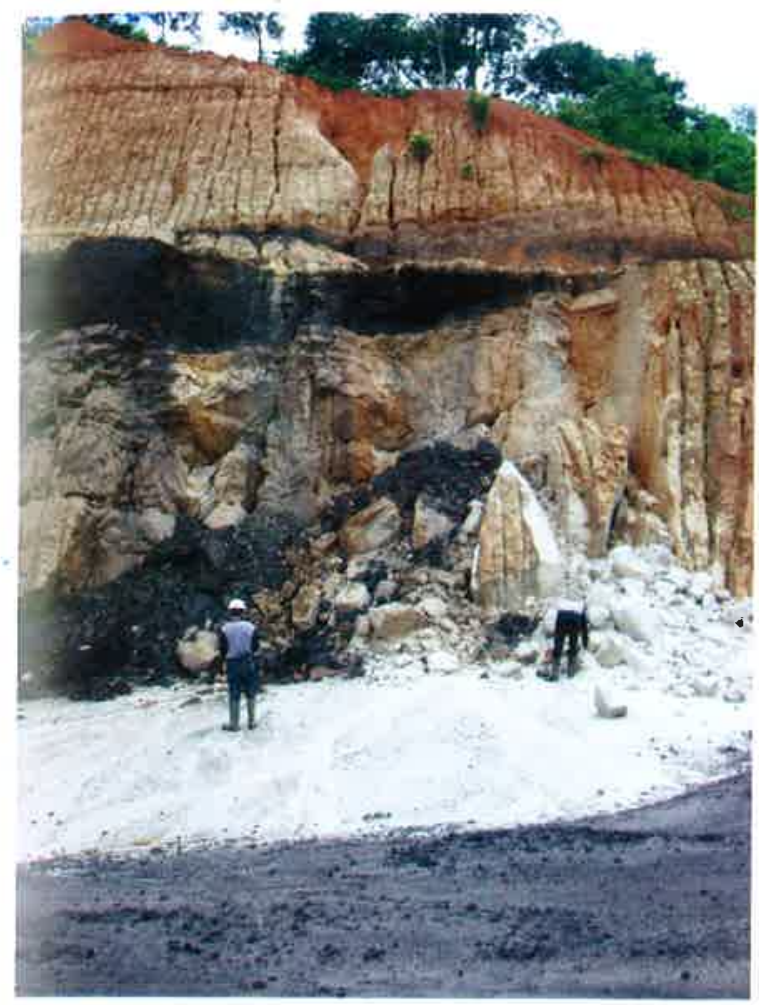

Gambar 5. Singkapan batupasir kuarsa pada dinding pit tambang batubara (Djunaedi dkk, 2008

\section{Pasir Kuarsa}

Pasir kuarsa dijumpai sebagai lapisan penyusun pada endapan batubara (Gambar 5). Pasir kuarsa adalah bahan galian yang dapat digunakan untuk berbagai bahan industri seperti industri gelas kaca, semen, bata tahan api, pengecoran logam, bahan baku pembuatan tegel dan mosaik keramik, bahan baku fero silikon, silikon carbida, ampelas, pasir filter dan glass wool. Pasir kuarsa biasanya ditemukan sebagai lapisan penutup ataupun berselingan dengan lapisan batubara, sehingga pada penambangan batubara, bahan galian ini akan ikut tergali.

\section{Abu Batubara}

Di Indonesia, kebutuhan energi untuk pembangkit listrik masih sangat bergantung pada pembakaran bahan bakar fosil seperti batubara, minyak bumi dan gas. Pembakaran batubara untuk energi menghasilkan limbah berupa abu batubara yang sebagian besar berasal dari pembangkit listrik tenaga uap (PLTU).

Abu terbang dapat dimanfaatkan sebagai adsorben untuk menyisihkan polutan pada gas - buang pada proses pembakaran yang berpotensi merusak lingkungan; "seperti gas sulfur oksida yang menyebabkan hujam asam, gas nitrogen oksida yang menyebabkan pemanasan global, dan merkuri $(\mathrm{Hg})$ yang berbahaya bagi makhluk hidup.

Komponen utama dari abu terbang batubara yang berasal dari pembangkit listrik adalah silika $\left(\mathrm{SiO}_{2}\right)$, alumina, $\left(\mathrm{Al}_{2} \mathrm{O} 3\right)$, dan besi oksida $\left(\mathrm{Fe}_{2} \mathrm{O} 3\right)$, sisanya berupa karbon, kalsium, magnesium, dan belerang Rumus empiris abu terbang batubaraadalah:Si ${ }_{10} \mathrm{Al}_{0.45} \mathrm{Ca}_{0.51} \mathrm{Na}_{0.047} \mathrm{Fe}_{0039} \mathrm{Mg}_{0.020 \text { - }}$ $\mathrm{K}_{0013} \mathrm{Ti}_{0011}$

Tabel 1.

Komposisi kimia abu terbang batubara

(Putri, 2008)

\begin{tabular}{|l|l|l|l|}
\hline Komponen & Bituminous & $\begin{array}{l}\text { Sub- } \\
\text { bituminous }\end{array}$ & Lignite \\
\hline $\mathrm{SiO}_{2}$ & $20-60 \%$ & $40-60 \%$ & $15-45 \%$ \\
$\mathrm{Al}_{2} \mathrm{O}_{3}$ & $5-35 \%$ & $20-30 \%$ & $10-25 \%$ \\
$\mathrm{Fe}_{2} \mathrm{O}_{3}$ & $10-40 \%$ & $4-10 \%$ & $4-15 \%$ \\
$\mathrm{CaO}$ & $1-12 \%$ & $5-30 \%$ & $15-40 \%$ \\
$\mathrm{MgO}$ & $0-5 \%$ & $1-6 \%$ & $3-10 \%$ \\
$\mathrm{SO}_{3}$ & $0-4 \%$ & $0-2 \%$ & $0-10 \%$ \\
$\mathrm{Na}_{2} \mathrm{O}$ & $0-4 \%$ & $0-2 \%$ & $0-6 \%$ \\
$\mathrm{~K}_{2} \mathrm{O}$ & $0-3 \%$ & $0-4 \%$ & $0-4 \%$ \\
$\mathrm{LOI}$ & $0-15 \%$ & $0-3 \%$ & $0-5 \%$ \\
\hline
\end{tabular}

Sifat kimia dari abu terbang batubara dipengaruhi oleh jenis batubara yang dibakar dan teknik penyimpanan serta penanganannya. Pem-bakaran batubara lignit dan sub-bituminous menghasilkan abu terbang dengan kalsium dan magnesium oksida lebih banyak daripada batubara bituminous, namun, memiliki kandungan silika, alumina, dan karbon yang lebih sedikit dibandingkan batubara bituminous (Trihadiningrum dan Sari, 2004).

Produksi abu terbang batubara (fly ash) didunia pada tahun 2000 diperkirakan berjumlah 349 milyar ton. Penyumbang produksi abu terbang batubara terbesar adalah sektor pembangkit listrik. Produksi abu terbang dari pembangkit listrik di Indonesia terus meningkat, pada tahun 2000 jumlahnya mencapai 1,66 milyar ton dan diperkirakan mencapai 2 milyar ton pada tahun 2006.

Abu terbang batubara umumnya dibuang di landfill atau ditumpuk begitu saja di dalam area industri. Saat ini umumnya abu terbang batubara digunakan sebagai salah satu bahan campuran pembuat beton. Selain itu abu batubara memiliki berbagai kegunaan yang amat beragam:

1. Bahan campuran beton

2. Penimbun lahan bekas pertambangan

3. Recovery magnetit, cenosphere, dan karbon

4. Bahan baku keramik, gelas, batu bata, dan refraktori

5. Bahan penggosok (polisher) 
6. Filler aspal, plastik, dan kertas

7. Bahan baku semen

8. Aditif dalam pengolahan limbah (waste stabilization)

9. Konversi menjadi zeolit dan adsorben

Konversi abu terbang batubara menjadi zeolit dan adsorben merupakan contoh pemanfaatan efektif dari abu terbang batubara. Keuntungan adsorben berbahan baku abu terbang batubara adalah biayanya yang murah. Selain itu, adsorben tersebut dapat digunakan baik untuk pengolahan limbah gas maupun limbah cair. Adsorben ini dapat digunakan dalam penyisihan logam berat dan senyawa organik pada pengolahan limbah. Abu terbang batubara dapat dipakai secara langsung sebagai adsorben atau dapat juga melalui perlakuan kimia dan fisik tertentu sebelum menjadi adsorben.

Zeolit yang disintesis dari abu terbang batubara banyak digunakan untuk keperluan pertanian dan dikonsumsi untuk pemurnian air. Zeolit dibuat dengan cara mengkonversi aluminosilikat yang terdapat pada abu terbang batubara menjadi kristal zeolit melalui reaksi hidrotermal (Putri, 2008).

Produksi abu terbang batubara (fly ash) didunia pada tahun 2000 diperkirakan berjumlah 349 milyar ton. Penyumbang produksi abu terbang batubara terbesar adalah sektor pembangkit listrik. Produksi abu terbang dari pembangkit listrik di Indonesia terus meningkat, pada tahun 2000 jumlahnya mencapai 1,66 milyar ton dan diperkirakan mencapai 2 milyar ton pada tahun 2006.

Abu terbang batubara umumnya dibuang di landfill atau ditumpuk begitu saja di dalam area industri. Saat ini umumnya abu terbang batubara digunakan sebagai salah satu bahan campuran pembuat beton. Selain itu abu batubara memiliki berbagai kegunaan yang amat beragam:

1. Bahan campuran beton

2. Penimbun lahan bekas pertambangan

3. Recovery magnetit, cenosphere, dan karbon

4. Bahan baku keramik, gelas, batu bata, dan refraktori

5. Bahan penggosok (polisher)

6. Filler aspal, plastik, dan kertas

7. Bahan baku semen

8. Aditif dalam pengolahan limbah (waste stabilization)

9. Konversi menjadi zeolit dan adsorben

Konversi abu terbang batubara menjadi zeolit dan adsorben merupakan contoh pemanfaatan

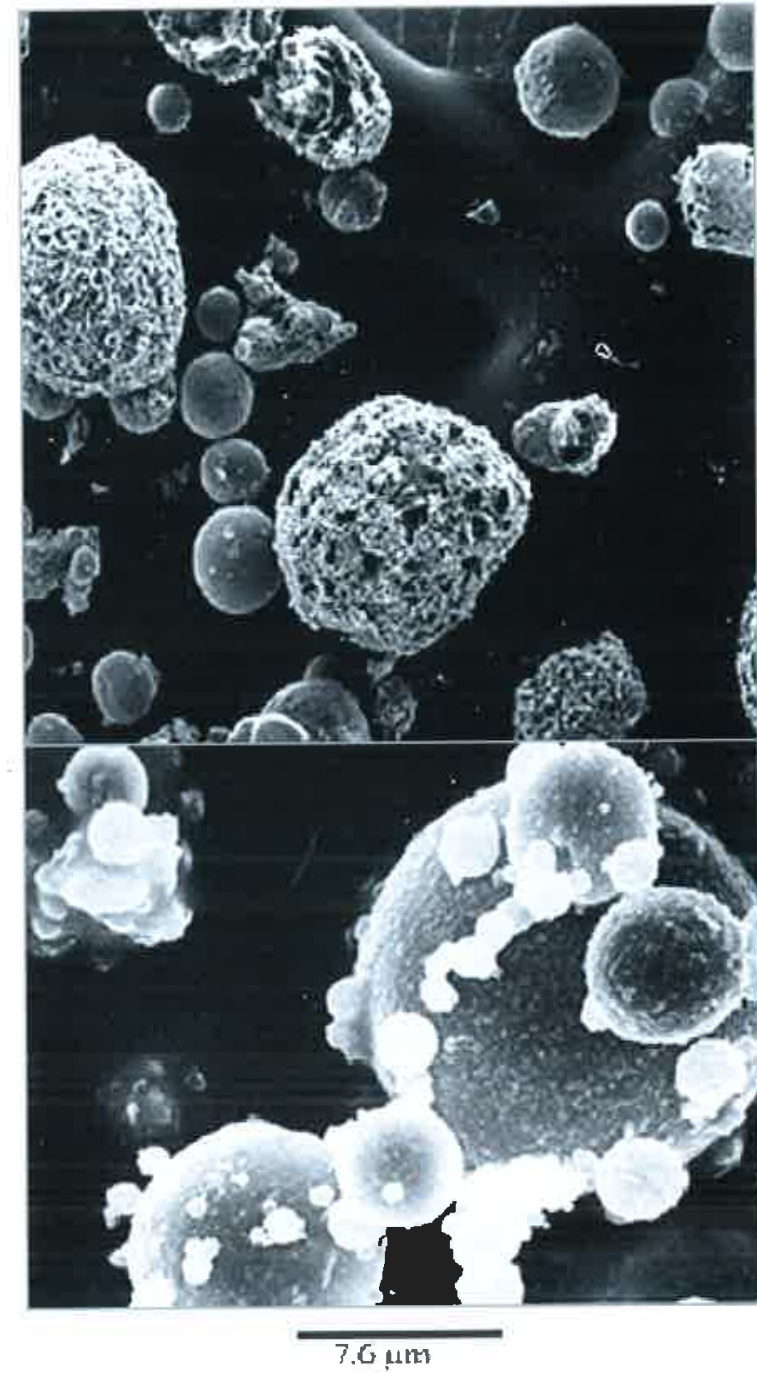

\section{Gambar 6. Abu batubara hasil dari scanning electron microscopy (Putri, 2008)}

efektif dari abu terbang batubara. Keuntungan adsorben berbahan baku abu terbang batubara adalah biayanya yang murah. Selain itu, adsorben tersebut dapat digunakan baik untuk pengolahan limbah gas maupun limbah cair. Adsorben ini dapat digunakan dalam penyisihan logam berat dan senyawa organik pada pengolahan limbah. Abu terbang batubara dapat dipakai secara langsung sebagai adsorben atau dapat juga melalui perlakuan kimia dan fisik tertentu sebelum menjadi adsorben.

Zeolit yang disintesis dari abu terbang batubara banyak digunakan untuk keperluan pertanian dan dikonsumsi untuk pemurnian air. Zeolit dibuat dengan cara mengkonversi aluminosilikat yang terdapat pada abu terbang batubara menjadi kristal zeolit melalui reaksi hidrotermal (Putri, 2008). 


\section{MAKALAH ILMAH}

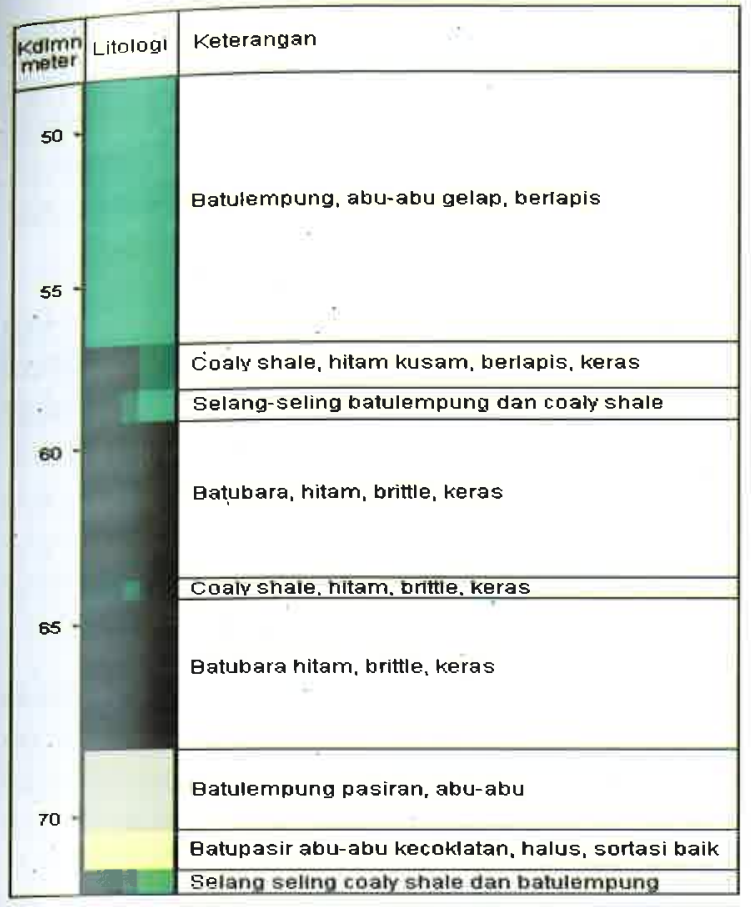

Gambar 7. Log litologi, pada tambang batubara di Kuantan Singingi,

Riau (modifikasi dari Hutamadi, 2008)

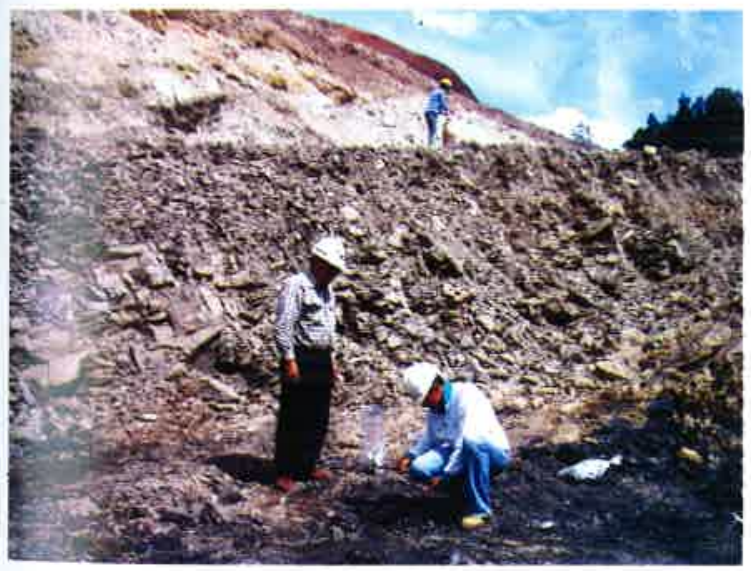

Gambar 8. Lapisan bitumen padat pada tambang batubara, Tangko, Riau (Hutamadi dkk, 2008)

\section{Bitumen Padat}

Contoh keterdapatan bahan galian ekonomi lainnya di lingkungan endapan batubara dapat dijumpai di wilayah pertambangan daerah Tangko, kabupaten Kuantan Singingi. Di daerah penambangan ditemukan sebaran bitumen padat dan juga coaly-shale dengan ketebalan berkisar 0,30-1,70 m (Gambar 7) dalam jumlah yang cukup signifikan. Dari hasil analisis retort, kandungan minyak dalam batuan ini cukup bervariasi antara $30-220$ liter/ton, diharapkan bitumen padat dan coaly-shale ini dapat dimanfaatkan menjadi sumber daya energi alternatif (Hutamadi dkk, 2008).

\section{BM}

Batubara, disamping dapat dimanfaatkan secara langsung sebagai bahan bakar, juga memiliki kandungan gas methan yang dapat dimanfaatkan sebagai sumber energi. Gas methan yang terperangkap dalam lapisan batuabara (coalbed methane/CBM), terbentuk secara alamiah pada proses pembentukan batubara.

Dibandingkan dengan batubara, gas methan merupakan sumber energi yang lebih ramah lingkungan. Disamping itu, gas methan yang dihasilkan oleh batubara memiliki kadar pengotor (impurities) yang lebih kecil bila dibandingkan dengan gas bumi, sedangkan dari sisi ekonomis biaya produksi gas methan relatif lebih murah dibandingkan dengan gas bumi (Wibisono, 2008).

Gas Methane dalam batubara pertamakali dikenal karena keberadaannya yang sering menimbulkan masalah dalam penambangan bawah tanah. Kecelakaan tambang akibat dari ledakan gas dalam sejarah pertambangan batubara telah memakan banyak korban. Kecelakaan ini terjadi ketika gas methan yang terkumpul dalam tambang bawah tanah terkena oksigen sehingga meledak. Gas dalam batubara juga beracun untuk para penambang jika terhirup dalam jangka waktu yang cukup lama. Baru sekitar 15 hingga 20 tahun yang lalu, gas methan mulai diproduksi secara komersial sebagai sumber energi.

Negara-negara yang telah memanfaatkan CBM secara ekstensif sebagai sumber energi diantaranya adalah Amerika, Canada, China dan Australia. Di Amerika sebagai contoh, CBM dianggap sebagai sumberdaya energi yang sangat penting. Demikian juga di Australia. Di negara-negara tersebut, industri CBM telah berkembang pesat dan termasuk salah satu yang paling maju di dunia.

Selain sebagai sumber energi, coalbed methan juga dapat dieksplorasi untuk menghindari kemungkinan keracunan, ledakan atau kebakaran pada tambang bawah tanah 
Di beberapa daerah penghasil batubara di Indonesia seperti di Sumatra Selatan, Kalimantan Selatan dan Kalimantan Timur, tercatat potensi CBM yang cukup signifikan. Saat ini pemerintah memberikan perhatian cukup besar bagi pengembangan CBM di Indonesia. CBM dianggap sebagai salah satu sumber energi potensial pengganti minyak dan gas bumi. Dengan diterbitkannya regulasi yang mengatur pengusahaan CBM di Indonesia, peluang untuk mengusahakan CBM secara komersial telah terbuka.

\section{PEMBAHASAN}

Batubara terbentuk berasosiasi dengan batuan lain. Komponen penyusun batubara dapat mengandung beberapa mineral maupun gas yang bernilai ekonomi. Lapisan sedimen lainnya yang biasa ditemukan berselingan dengan lapisan batubara juga bisa bernilai ekonomi.

Pengelolaan sumber daya batubara dengan memperhitungkan potensi lain yang terdapat bersamaan akan memberikan nilai tambah pada eksploitasi batubara. Sebagai contoh, bahan galian yang mempunyai nilai ekonomi rendah, yang ikut tergali pada penambangan batubara, dapat dimanfaatkan tanpa memerlukan biaya penggalian. Demikian juga limbah pembakaran batubara dapat dimanfaatkan, sehingga tidak menjadi bahan yang dapat menurunkan kualitas lingkungan.

Kandungan unsur atau bahan pencemar dalam batubara khsususnya yang mempunyai sifat radioaktif dan dapat meningkatkan paparan radioaktivitas alam, perlu penanganan agar tidak menyebabkan degradasi lingkungan. Sampah yang dihasilkan dari pembangkit listrik tenaga batubara dapat bersifat lebih radioaktif daripada yang dihasilkan dari sampah nuklir. Radionuklida alam yang terkandung dalam batubara berupa kalium, uranium, thorium, dan produk-produk peluruhannya. Pada wujud batubara unsur-unsur tersebut masih pada batas aman. Akan tetapi ketika batubara terbakar menjadi abu, uranium dan thorium dapat terkonsentrasi menjadi 10 kali lipat dari kondisi awalnya.

Emisi gas $\mathrm{CO}_{2}$ yang dihasilkan dari PLTU batubara dapat direduksi jumlahnya dengan melengkapi unit pembangkit dengan fasilitas pengolahan gas buang. Pada fasilitas ini, gas
$\mathrm{CO}_{2}$ dapat direaksikan dengan kalsium hidroksida sehingga menghasilkan kalsium karbonat. Kalsium karbonat dapat dimanfaatkan sebagai bahan dasar pada' industri makanan, farmasi dan industri konstruksi (Finahari dkk, 2008)

Eksplorasi dan eksploitasi bahan galian lain yang berasosiasi dengan batubara, seperti lempung dan pasir kuarsa dapat dilakukan bersamaan dengan penambangan batubara Dengan jalan ini, diharapkan nilai ekonomi yang dihasilkan lebih besar dibandingkan dengan kegiatan eksplorasi dan eksploitasi yang sematamata untuk mendapatkan bahan galian tersebut.

Eksploitasi CBM disertai dengan proses pemompaan air tanah (dewatering). Air tanah yang dikeluarkan dapat dimanfaatkan sesuai dengan kualitasnya, terutama untuk irigasi pertanian.

Pemanfaatan sumber daya batubara berpotensi menghasilkan juga komoditas ekonomi lainnya. Oleh karena itu ketika memperhitungkan potensi ekonomi suatu wilayah cekungan batubara sebaiknya juga dipertimbangkan keterdapatan bahan tambang lainnya yang bernilai ekonomis.

\section{KESIMPULAN}

Bersamaan. dengan keterdapatan batubara, dapat dijumpai keterdapatan komoditi lain yang bernilai ekomomi. Komoditi tersebut dapat berupa batuan sedimen lain yang berasosiasi dengan batubara, maupun komponen dalam batubara itu sendiri.

Batupasir, batulempung maupun bitumen padat yang biasa ditemukan sebagai lapisan penutup atau berselingan dengan lapisan batubara, dalam penambangan batubara, ketika ikut tergali umumnya diperlakukan sebagai sampah (waste). Padahal, batuan tersebut memiliki potensi tersendiri. Penambangan batuan tersebut jika dilakukan bersamaan dengan penambangan batubara, akan memberikan nilai ekonomi lebih, karena tidak membutuhkan biaya khusus.

Pemanfaatan abu batubara sisa dari pembakaran batubara selain mendatangkan manfaat secara ekonomi, juga mencegah degradasi lingkungan sebagai akibat pembuangan abu batubara yang dapat mencemari 
lingkungan. Hanya saja dalam pemanfaatan abu batubara perlu juga dengan mencermati keterdapatan kandungan unsur radioaktif.
Kandungan gas methan pada batubara dapat dimanfaatkan secara ekonomi, sebagai sumber energi yang relatif ramah lingkungan.

\section{ACUAN}

Djunaedi, E.K., Suherman, W., Kamal, S., Juliawan, N., 2008. Penelitian Bahan Galian Lain/Mineral Ikutan di Wilayah Pertambangan Daerah Kabupaten Kutai Kartanegara, Provinsi Kalimantan Timur. Pusat Sumber Daya Geologi, Bandung.

Finahari, I.N., Djati, H.S., Susiati, H., 2008. Emisi Gas CO2 dan Polutan Radioaktif dari PLTU Batubara. Batan. www.batan.go.id/

Gunradi, R., Hutamadi, R., Ishlah, T., Suprapto, S.J., 2004. Pemantauan dan Evaluasi Konservasi Sumber Daya Mineral di Daerah Kabupaten Muaraenim, Provinsi Sumatera Selatan. Direktorat Inventarisasi Sumber Daya Mineral, Bandung

Hutamadi, R., Pohan, M.P., 2008. Penelitian Bahan Galian Lain/Mineral Ikutan di Wilayah Pertambangan Tangko, Kabupaten Kuantan Sengingi, Provinsi Riau. Pusat Sumber Daya Geologi, Bandung.

Putri, M.,2008. Abu Batubara SebagaiAdsurben. Majari Magazine

Trihadiningrum, Y., Sari, Y., 2004. Kajian Status Abu Batubara Sebagai Limbah Bahan Berbahaya dan Beracun. Jurusan Teknik Lingkungan, FTSP, Institut Teknologi Surabaya, Surabaya

Wibisono, S.A., Analisa Kandungan Gas Methan Dalam Batubara Pada Titik Bor B-)1 dan B-02 Daerah Loa Lepu, Kab. Kutai Kartanegara, Kalimantan Timur. Buletin Sumber Daya Geologi Vol 3 No 3. Bandung

Widowati, A., 2008. Abu Batubara Lebih Radioaktif dari Sampah Nuklir. Pusat Teknologi Nuklir Bahan dan Radiometri, Bandung 